\title{
Effect of Phosphate and Hydrogen Peroxide on Bacterial Community and Removal Efficiency of Biological Activated Carbon (BAC) Process for Enhanced Biofiltration
}

\author{
Eun-Young Jung ${ }^{1 \oplus} \cdot$ Byungryul $\mathrm{An}^{2 \oplus} \cdot$ Heejong Son ${ }^{1,+\oplus}$ \\ 'Water Quality Institute, Busan Water Authority \\ ${ }^{2}$ Department of Civil Engineering, Sangmyung University
}

(Received November 25, 2020; Revised December 3, 2020; Accepted December 10, 2020)

Objectives: The correlation between the organic material removal ability of the enhanced BAC process injected by the phosphate $\left(\mathrm{PO}_{4}-\mathrm{P}\right)$ and/or hydrogen peroxide $\left(\mathrm{H}_{2} \mathrm{O}_{2}\right)$ and attached bacterial community was evaluated.

Methods: As pilot plant for the purification of raw water downstream of Nakdong river, 4 acrylic columns with an inner diameter of $20 \mathrm{~cm}$ and a height of $250 \mathrm{~cm}$ were operated at an empty bed contact time of 20 minutes. The four BAC columns are as followed; conventional BAC (control-BAC), enhanced BAC with phosphorus $\left(\mathrm{PO}_{4}-\mathrm{P}+\mathrm{BAC}\right)$, enhanced $\mathrm{BAC}$ with hydrogen peroxide $\left(\mathrm{H}_{2} \mathrm{O}_{2}+\mathrm{BAC}\right)$, and enhanced $\mathrm{BAC}$ with phosphorus and hydrogen peroxide $\left(\mathrm{PO}_{4}-\mathrm{P}+\mathrm{H}_{2} \mathrm{O}_{2}+\mathrm{BAC}\right) .0 .01 \mathrm{mg} / \mathrm{L}$ of $\mathrm{PO}_{4}-\mathrm{P}$ and $1 \mathrm{mg} / \mathrm{L}$ of $\mathrm{H}_{2} \mathrm{O}_{2}$ were added in influent in the enhanced BAC, respectively. After 18 months of operation, activated carbon was collected from the top of each BAC column and 16S rRNA amplicon sequence analysis was performed.

Results and Discussion: The long-term addition of $\mathrm{PO}_{4}-\mathrm{P}$ and $\mathrm{H}_{2} \mathrm{O}_{2}$ contributes the increase of biomass and activity of attached bacteria, respectively. In the attached bacterial community of conventional and enhanced process, Proteobacteria phylum is the most dominant specie and both $\alpha$-Proteobacteria class and $\beta$-Proteobacteria class are also highly present. Each enhanced BAC exhibits very high bacterial community similarity based on the composition of various genera but it is completely different with conventional BAC. In particular, Bradyrhizobium, Sphingomonas, Methylobacterium, Sphingobium, Belnapia, Burkholderia, Polaromonas, and Desulfuromonas, which have excellent metabolism functions for a wide range of organic substrates, are highly dominated in the enhanced BAC process. The concentration of Biodegradable Dissolved Organic Carbon (BDOC) is obtained close to 0.15 $\mathrm{mg} / \mathrm{L}$ for conventional BAC and less than $0.15 \mathrm{mg} / \mathrm{L}$ for enhanced BAC process, respectively. In general, the higher BDOC concentration can result in reducing biostability in water supply and distribution system when the residual chlorine concentration does not meet requirements. As result, less than $0.15 \mathrm{mg} / \mathrm{L}$ BDOC accomplished by $\mathrm{PO}_{4}-\mathrm{P}$ and $\mathrm{H}_{2} \mathrm{O}_{2}$ enhances the biostability.

Conclusions: Compared to the conventional BAC process, the biomass and activity of attached bacteria and the ratio of the organization composition of the bacteria insides (genus) are considerably higher in the enhanced BAC process. These results achieve higher water quality and improve biostability.

Keywords: Biological Activated Carbon (BAC), Bacterial Community, Hydrogen Peroxide, Phosphate, Biodegradable Dissolved Organic Carbon (BDOC)

The Korean text of this paper can be translated into multiple languages on the website of http:/jksee.or.kr through Google Translator. 


\title{
연구논문
}

\section{강화 생물여과를 위한 인산염과 과산화수소 투입이 생물활성탄 공정의 박테리아 군집과 제거효율에 미치는 영향}

\author{
정은영 $^{1 \odot} \cdot$ 안병렬 $^{2 \oplus} \cdot$ 손희종 $^{1,+\odot}$ \\ ${ }^{1}$ 부산광역시 상수도사업본부 수질연구소 \\ 2상명대학교 토목공학과
}

목적 : 인산염 $\left(\mathrm{PO}_{4}-\mathrm{P}\right)$ 과 과산화수소 $\left(\mathrm{H}_{2} \mathrm{O}_{2}\right)$ 를 투입하는 강화 $\mathrm{BAC}$ 공정의 향상된 유기물질 제거능과 부착 박테리아 군집과의 연관성을 평가하고자 하였다.

방법: 낙동강 하류원수를 정수처리하는 파일럿 플랜트를 이용하여 내경 $20 \mathrm{~cm}$, 높이 $250 \mathrm{~cm}$ 의 아크릴 컬럼 4 개를 사용하여 공탑 체류시간 20 분으로 운전하였다. 4 개의 $\mathrm{BAC}$ 컬럼들은 재래식 $\mathrm{BAC}$ (control-BAC), 인을 투입한 강 화 $\mathrm{BAC}\left(\mathrm{PO}_{4}-\mathrm{P}+\mathrm{BAC}\right)$, 과산화수소를 투입한 강화 $\mathrm{BAC}\left(\mathrm{H}_{2} \mathrm{O}_{2}+\mathrm{BAC}\right)$ 및 인과 과산화수소를 함께 투입한 강화 $\mathrm{BAC}\left(\mathrm{PO}_{4}-\mathrm{P}+\mathrm{H}_{2} \mathrm{O}_{2}+\mathrm{BAC}\right)$ 이다. $\mathrm{PO}_{4}-\mathrm{P}$ 를 투입한 강화 $\mathrm{BAC}$ 들의 경우, $\mathrm{BAC}$ 유입수에 $0.010 \mathrm{mg} / \mathrm{L}$ 의 농도로 $\mathrm{PO}_{4}-\mathrm{P}$ 를 추가로 보충하였으며, $\mathrm{H}_{2} \mathrm{O}_{2}$ 를 투입한 강화 $\mathrm{BAC}$ 들에서는 $\mathrm{H}_{2} \mathrm{O}_{2}$ 를 $\mathrm{BAC}$ 유입수에 $1 \mathrm{mg} / \mathrm{L}$ 의 농도로 투입하였다. 1 년 6 개월 운전 후에 각 $\mathrm{BAC}$ 컬럼의 상부에서 활성탄을 채취하여 $16 \mathrm{~S} \mathrm{rRNA}$ 앰플리콘 시퀀싱 분석을 하였다.

결과 및 토의: 강화 $\mathrm{BAC}$ 공정에서 장기간 투입된 인산염 $\left(\mathrm{PO}_{4}-\mathrm{P}\right)$ 은 부착 박테리아의 생체량의 증가에 기여하였고, 과산화수소 $\left(\mathrm{H}_{2} \mathrm{O}_{2}\right)$ 는 부착 박테리아의 활성도 증진에 기여하였다. 재래식 $\mathrm{BAC}$ 공정과 강화 $\mathrm{BAC}$ 공정들의 부착 박 테리아 군집에서는 Proteobacteria문의 우점율이 가장 높았으며, $\alpha$ - 및 $\beta$-Proteobacteria강의 우점율이 높게 나타났 다. 박테리아 군집 내 다양한 속(genus)들의 구성비율을 바탕으로 한 박테리아 군집 유사도의 경우, 강화 BAC들은 서로 유사하게 나타났으며, 재래식 BAC 공정과는 명확하게 구분되었다. 특히, 광범위한 유기기질들에 대해 우수한 대사능을 가진 Bradyrhizobium속, Sphingomonas속, Methylobacterium속, Sphingobium속, Belnapia속, Burkholderia 속, Polaromonas속, Desulfuromonas속들이 강화 BAC 공정들에서 높은 비율로 우점하여 재래식 BAC 공정과는 많 은 차이를 나타내었다. $\mathrm{BDOC}$ 제거능으로 평가된 처리수의 수질의 경우도 재래식 $\mathrm{BAC}$ 공정에서는 처리수 중의 $\mathrm{BDOC}$ 농도가 $0.15 \mathrm{mg} / \mathrm{L}$ 부근으로 나타나 관망에서 잔류염소 농도가 감소하면 생물학적 안전성이 위협받을 가능 성이 존재한 반면, 인산염 $\left(\mathrm{PO}_{4}-\mathrm{P}\right)$ 과 과산화수소 $\left(\mathrm{H}_{2} \mathrm{O}_{2}\right)$ 를 투입한 강화 $\mathrm{BAC}$ 공정 처리수에서는 평균 $\mathrm{BDOC}$ 농도가 $0.15 \mathrm{mg} / \mathrm{L}$ 미만으로 관망에서의 생물학적 안전성에 문제가 없었다.

결론 : 재래식 $\mathrm{BAC}$ 공정에 비해 강화 $\mathrm{BAC}$ 공정에서는 부착 박테리아의 생체량과 활성도뿐만 아니라 유기물 제거 능이 뛰어난 박테리아 속(genus)들의 구성비율이 월등히 높아 처리수의 수질도 재래식 BAC 공정에 비해 생물학적 으로 안전하였다.

주제어: 생물활성탄, 박테리아 군집, 과산화수소, 인, 생분해 가능한 유기탄소

\section{1. 서론}

국내의 대형 정수장들에서 운영되고 있는 생물활성탄 (biological activated carbon, $\mathrm{BAC}$ ) 공정은 활성탄의 세공에 다양한 박테리아들이 생물막을 형성하여 수중에 잔존하는 오 염물질을 분해·제거하는 공정이다. ${ }^{1)} \mathrm{BAC}$ 공정은 전단에 위 치한 오존처리 공정과 조합하여 운영된다. 오존처리에 의해 난분해성 유기오염물질은 저분자화·친수성화되어 생물분해
능이 증진되며, 후단의 $\mathrm{BAC}$ 공정에 의해 용이하게 제거된다. ${ }^{1)}$ 수중의 소독부산물 전구물질, 이취유발 물질, 조류독소, 내분 비계 장애물질, 잔류 의약물질, 개인위생용품 첨가물질 등의 제거 ${ }^{2-4)}$ 뿐만 아니라 관망에서의 미생물 재성장능 저감 목적으 로 운영되고 있다. ${ }^{5)}$

$\mathrm{BAC}$ 공정은 생물학적 처리공정의 일종으로 수온하, 활성탄 재질 ${ }^{7)}$, 공탑 체류시간(empty bed contact time, EBCT ${ }^{8)}$, 역세 척 조건"), 유입수 성상미 등 많은 인자들이 부착 생물막의 
생체량과 활성도에 영향을 미쳐 $\mathrm{BAC}$ 공정의 운전효율에 변화 를 초래한다. ${ }^{1,11)}$ 따라서, 활성탄 부착 생물막의 생체량과 활성 도를 안정적으로 유지하는 것이 $\mathrm{BAC}$ 공정의 운전에 있어서 매우 중요하다.

최근에는 영양염 $(\mathrm{N}, \mathrm{P})$ 또는 과산화수소를 투입하여 $\mathrm{BAC}$ 공정의 운전효율을 증진시키는 강화 $\mathrm{BAC}$ (enhanced $\mathrm{BAC}$ ) 공정에 대한 연구가 많이 진행되고 있다. ${ }^{12-14)}$ 강화 $\mathrm{BAC}$ 공정 은 $\mathrm{BAC}$ 공정 유입수에 영양염과 과산화수소를 인위적으로 투입하여 활성탄에 형성된 생물막의 생체량과 활성을 증진시 켜 제거효율 상승을 유도하는 원리이다. ${ }^{10,12)}$ 정수처리 공정 중 응집공정에서 원수 중에 잔존하는 대부분의 인 $(\mathrm{P})$ 이 제거 되어 후단의 $\mathrm{BAC}$ 공정으로는 $0.01 \mathrm{mg} / \mathrm{L}$ 이하의 농도로 인이 유입된다. ${ }^{15)}$ 따라서 $\mathrm{BAC}$ 공정에서 인(P)이 제한인자로 작용 하면 부착 생물막의 물리적 구조와 형태 변형으로 손실수두 증가가 증가하고, 오염물질 제거능이 감소한다. ${ }^{16)}$ 박테리아의 생장과 증식에 필요한 $\mathrm{C}(\mathrm{BDOC}): \mathrm{N}\left(\mathrm{NH}_{4}-\mathrm{N}\right): \mathrm{P}\left(\mathrm{PO}_{4}-\mathrm{P}\right)$ 는 $100: 10: 1(=1 \mathrm{mg} / \mathrm{L}: 0.117 \mathrm{mg} / \mathrm{L}: 0.026 \mathrm{mg} / \mathrm{L})$ 로 알려져 있 다. ${ }^{17)}$ 강화목적으로 사용되는 과산화수소는 생물막에 용존산 소 공급뿐만 아니라 생물막에서 유기 화합물의 산화를 촉진시 키도록 과산화 효소 발현을 유도하며 ${ }^{18)}$, 비활성 생체량을 효과 적으로 산화·제거시키는 것으로 보고되고 있다. ${ }^{19,20)}$

생물학적 처리공정에서 미생물 군집에 대한 정보는 처리효 율을 향상에 기여하는 중요한 수단으로 작용한다. ${ }^{21,22)}$ 생물여 과 공정에 대한 여러 연구들에서는 유입수의 수질 ${ }^{23)}$, 수온 ${ }^{24)}$, 운전 조건 ${ }^{25}$ 및 여재(media) 유형 ${ }^{26}$ 과 관련되어 발생하는 부착 박테리아 군집의 차이를 평가하였다. Lautenschlager 등 ${ }^{27)}$ 은 동일한 수질조건에서 유사한 군집구조를 가진 다양한 생물여 과 공정들에 대한 박테리아 분류군(Proteobacteria 비율)을 평 가해 본 결과, $\mathrm{BAC}$ 공정에서는 $74.2 \%$, 급속 모래여과 공정은 $54 \%$ 및 완속 모래여과 공정은 $45 \%$ 로 나타나 여재 차이에 따라 Proteobacteria 비율의 구성비율에 많은 차이가 있음을 보고하였다. 또한, Vignola 등 ${ }^{26}$ 과 Lautenschlager 등 ${ }^{27)}$ 의 연구 결과에서 제한적이지만 활성탄의 공극율, 표면 특성 및 흡착 용량 등이 부착 박테리아 군집에 영향을 미치는 것으로 보고 하고 있다.

최근에 보고된 활성탄 특성이 $\mathrm{BAC}$ 부착 박테리아 군집에 미치는 영향을 자세히 평가한 연구결과 ${ }^{28)}$ 에 따르면 상이한 재질(목탄계와 석탄계 재질)에서 기인한 표면 극성(surface polarity) 차이와 동일한 석탄계 재질인 경우에도 세공 크기
분포와 구조 차이가 부착 박테리아의 군집에 많은 영향을 미 치는 것으로 보고하고 있다.

박테리아는 고유한 기질 선호도 ${ }^{27,29)}$ 를 가지고 있어 BAC 공정에서 부착 박테리아 군집의 변화는 $\mathrm{BAC}$ 공정에서 제거할 수 있는 유기물질 종류의 변화를 의미하기 때문에 박테리아의 군집 특성을 평가하는 것은 $\mathrm{BAC}$ 공정의 운영에 있어서 매우 중요하다.

최근에는 수생 생태계의 미생물 군집 구조를 평가하기 위해 분자 생물학적 기법을 많이 사용하고 있다. 특히, 차세대 DNA 시퀀싱은 박테리아 또는 고세균의 $16 \mathrm{~S} \mathrm{rRNA}$ 를 시퀀싱하여 전체 미생물 군집구조를 분석하는 빠르고 정확한 방법으로 비배양 평가를 위한 기본기술로 빠르게 부상하고 있다. ${ }^{27,30,31)}$ $16 \mathrm{~S} \mathrm{rRNA}$ 를 표적으로 하는 것은 박테리아의 기능에 대한 정보를 제공하지는 않지만, 환경 또는 운영 조건의 변화로 인한 미생물 군집구조의 변화를 모니터링하는 목적으로 많이 활용되고 있다. ${ }^{32,33)}$

여러 연구결과들 ${ }^{12-14)}$ 에서 인산염 $\left(\mathrm{PO}_{4}-\mathrm{P}\right)$ 과 과산화수소 $\left(\mathrm{H}_{2} \mathrm{O}_{2}\right)$ 를 투입하는 강화 $\mathrm{BAC}$ 공정에서의 향상된 유기물질 제거능을 보고하고는 있으나 그 원인에 대해서는 단편적으로 부착 박테 리아의 생체량과 활성도 증가만을 보고하고 있다. ${ }^{14)}$ 본 연구에 서는 기존의 재래식 $\mathrm{BAC}$ 공정과 강화 $\mathrm{BAC}$ 공정 부착 박테리 아들에 대한 $16 \mathrm{~S}$ rRNA 앰플리콘 시퀀싱(amplicon sequencing) 분석을 통하여 강화 $\mathrm{BAC}$ 공정의 향상된 유기물질 제거능과 부착 박테리아 군집과의 연관성을 평가하고자 하였다.

\section{2. 실험재료 및 방법}

\section{1. 실험재료}

\subsubsection{BAC 공정 유입수}

$\mathrm{BAC}$ 공정의 유입수로는 낙동강 하류지역의 원수를 취수하 여 정수처리를 하는 파일럿 플랜트의 후오존 처리수를 사용하 였다. 후오존 투입농도는 실험기간 동안 $1 \mathrm{mg} \cdot \mathrm{O}_{3} / \mathrm{mg} \cdot \mathrm{DOC}$ 로 고정하여 운전하였다. 후오존 처리수는 저류조에서 30 분간 저류시켜 잔류 오존을 완전히 소모시킨 후 실험에 사용하였 다. 실험기간(1년 6개월) 동안의 유입수(후오존 처리수) 성상

을 Table 1에 나타내었다.

\subsubsection{BAC 공정 구성 및 운전}

$\mathrm{BAC}$ 는 낙동강 하류에 위치한 정수장의 오존/생물활성탄

Table 1. Characteristics of BAC influent water from Apr. 2019 to Oct. 2020.

\begin{tabular}{cccccc} 
& $\mathrm{pH}$ & $\mathrm{DOC}$ & $\mathrm{BDOC}$ & $\mathrm{PO}_{4}-\mathrm{P}$ & \multicolumn{2}{c}{ Temperature } \\
\cline { 2 - 5 } & $(-)$ & $(\mathrm{mg} / \mathrm{L})$ & $(\mathrm{mg} / \mathrm{L})$ & $(\mathrm{mg} / \mathrm{L})$ & $\left({ }^{\circ} \mathrm{C}\right)$ \\
Influent water & $6.9 \sim 7.8$ & $2.11 \sim 3.05$ & $0.30 \sim 0.84$ & $\mathrm{ND} \sim 0.013$ & $(0.69)^{\mathrm{a}}$ \\
\hline
\end{tabular}

\footnotetext{
a average concentration
} 

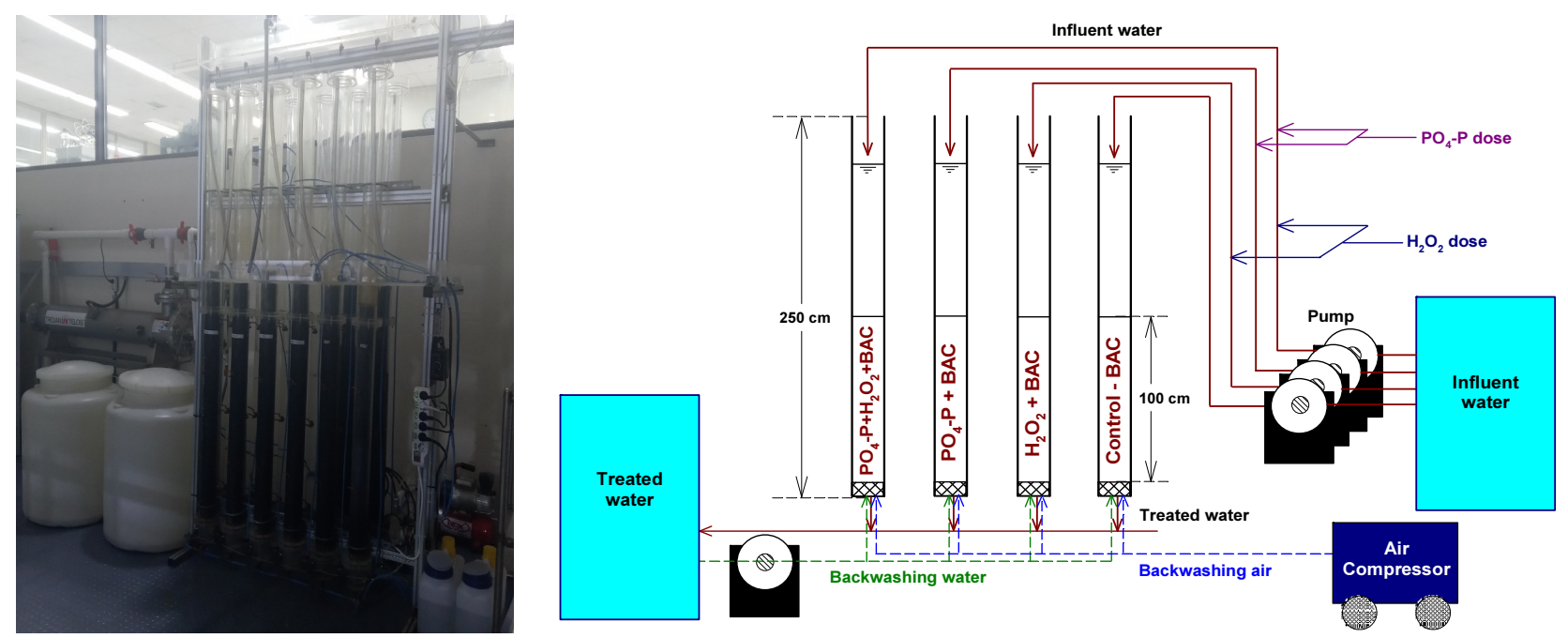

Fig. 1. Photograph and schematic diagram of BAC column system.

$\left(\mathrm{O}_{3} / \mathrm{BAC}\right)$ 공정에서 2 년 정도 사용된 석탄계 재질의 활성탄을 사용하였다. 정수장에서 채집한 $\mathrm{BAC}$ 화된 활성탄을 수돗물로 여러 번 세척한 후 잔류염소가 존재하는 수돗물에 침지시켜 7 일간 수돗물을 매일 2 회 갈아주면서 활성탄 부착 박테리아 군집의 활성도와 생체량을 인위적으로 감소시켰다. 잘 세척된 활성탄을 아크릴 컬럼(내경 $20 \mathrm{~cm}$, 높이 $250 \mathrm{~cm}$ ) 4 개에 층고 $100 \mathrm{~cm}$ 가 되도록 충진한 후, 1 년 6개월간 인산염 $\left(\mathrm{PO}_{4}-\mathrm{P}\right)$ 과 과산화수소 $\left(\mathrm{H}_{2} \mathrm{O}_{2}\right)$ 를 각각의 실험조건에 맞게 투입하며 본 연 구를 진행하였다.

저류조에서 잔류오존이 완전히 제거된 후오존 처리수를 펌 프로 각각의 $\mathrm{BAC}$ 컬럼들로 이송하였다. 각 $\mathrm{BAC}$ 컬럼들의 공탑 체류시간(empty bed contact time, EBCT)은 20분으로 고정하여 운전하였고, 역세척은 공세 3 분, 수세 10 분의 조건으 로 주 1 회 실시하였다.

4개의 BAC 컬럼들은 인산염 $\left(\mathrm{PO}_{4}-\mathrm{P}\right)$ 과 과산화수소 $\left(\mathrm{H}_{2} \mathrm{O}_{2}\right)$ 투입 유-무에 따라 재래식(대조군) $\mathrm{BAC}$ (control-BAC), $\mathrm{H}_{2} \mathrm{O}_{2}$ 만 투입한 $\mathrm{BAC}\left(\mathrm{H}_{2} \mathrm{O}_{2}+\mathrm{BAC}\right), \mathrm{PO}_{4}-\mathrm{P}$ 만 투입한 $\mathrm{BAC}\left(\mathrm{PO}_{4}-\mathrm{P}+\right.$ $\mathrm{BAC}), \mathrm{PO}_{4}-\mathrm{P}$ 와 $\mathrm{H}_{2} \mathrm{O}_{2}$ 를 함께 투입한 $\mathrm{BAC}\left(\mathrm{PO}_{4}-\mathrm{P}+\mathrm{H}_{2} \mathrm{O}_{2}+\right.$ $\mathrm{BAC})$ 로 나누어 동일한 조건으로 1년 6 개월간 운전하였다. $\mathrm{BAC}$ 컬럼 시스템 개략도(Fig.1)에서 볼 수 있듯이 각각의 $\mathrm{BAC}$ 컬럼으로 이송되는 후오존 처리수 공급라인에 희석된 $\mathrm{PO}_{4}-\mathrm{P}$ 와 $\mathrm{H}_{2} \mathrm{O}_{2}$ 공급용 정밀유량 펌프(Masterflex ${ }^{\circledR} \mathrm{L} / \mathrm{S}^{\circledR}$, Cole-Parmer, $\mathrm{USA}$ )를 설치하여 각각의 투입조건에 맞추어 $\mathrm{PO}_{4}-\mathrm{P}^{2} \mathrm{H}_{2} \mathrm{O}_{2}$ 를 투입하였다.

$\mathrm{PO}_{4}-\mathrm{P}$ 가 투입된 강화 $\mathrm{BAC}$ 컬럼들 $\left(\mathrm{PO}_{4}-\mathrm{P}+\mathrm{BAC}, \mathrm{PO}_{4}-\mathrm{P}+\right.$ $\mathrm{H}_{2} \mathrm{O}_{2}+\mathrm{BAC}$ )의 경우, 후오존 처리수에 잔존하는 $\mathrm{PO}_{4}-\mathrm{P}$ 농도에 더하여 추가적으로 $0.010 \mathrm{mg} / \mathrm{L}$ 의 $\mathrm{PO}_{4}-\mathrm{P}$ 를 더 투입하였다. ${ }^{14)}$ 실험기간 동안 후오존 처리수 중의 평균 $\mathrm{PO}_{4}-\mathrm{P}$ 농도는 Table 1 에서 볼 수 있듯이 $0.004 \mathrm{mg} / \mathrm{L}$ 였다. $\mathrm{H}_{2} \mathrm{O}_{2}$ 가 투입된 강화 $\mathrm{BAC}$ 컬럼들 $\left(\mathrm{H}_{2} \mathrm{O}_{2}+\mathrm{BAC}, \mathrm{PO}_{4}-\mathrm{P}+\mathrm{H}_{2} \mathrm{O}_{2}+\mathrm{BAC}\right)$ 의 경우는 $\mathrm{BAC}$ 로 유입된 $\mathrm{H}_{2} \mathrm{O}_{2}$ 농도가 $1 \mathrm{mg} / \mathrm{L}$ 가 되도록 운전하였다. $\mathrm{H}_{2} \mathrm{O}_{2}$ 와
$\mathrm{PO}_{4}-\mathrm{P}$ 는 각각 $30 \%$ 과산화수소(Sigma-aldrich, USA)와 $85 \%$ 인산(Sigma-aldrich, USA)을 희석하여 사용하였다.

\section{2. 실험방법}

\subsection{1. 부착 박테리아 생체량 및 활성도}

부착 박테리아의 생체량은 부착 박테리아 군집에서 추출한 ATP 농도로 평가하였다. 활성탄 $200 \mathrm{mg}$ (습중량)을 채집 후 Velten 등이 제시한 방법 ${ }^{34)}$ 으로 전처리하여 luminometer (Victor3, PerkinElmer, USA)로 분석하였다.

부착 박테리아의 활성도 ${ }^{35)}$ 는 ${ }^{3} \mathrm{H}$-thymidine이 활성탄에서 탈 리시킨 박테리아의 DNA에 흡수되는 양으로 평가하였다. 활성 탄 $1 \mathrm{~g}$ (습중량)을 채집·전처리 후 liquid scintillation analyzer (PerkinElmer, Quantulus 1220, USA)로 분석하여 얻어진 DPM (disintergrate per minute) 값으로 박테리아 DNA에 결합된 thymidine의 양을 계산하였다.

\subsection{2. 부착 박테리아 군집분석}

DNeasyPowerSoil Kit (Qiagen, Hilden, Germany)를 사용하 여 채집한 활성탄 시료들에서 DNA를 추출하였다. 추출된 DNA는 Quant-IT PicoGreen (Invitrogen, USA)을 사용하여 정 량하였다.

추출된 DNA의 염기서열 분석을 위한 library는 $16 \mathrm{~S}$ Metagenomic Sequencing Library (Illumina, USA)이며, 시험 방법에 따라 V3 및 V4 영역을 증폭하여 1차 $\mathrm{PCR}$ 은 $95^{\circ} \mathrm{C}$ 에서 30 초, $55^{\circ} \mathrm{C}$ 에서 30 초, $72^{\circ} \mathrm{C}$ 에서 30 초를 25 회 반복 수행하였 다. 증폭된 1차 산물은 AMPure (Agencourt Bioscience, USA) 를 사용하여 정제하였으며, 2차 PCR은 NexteraXT Indexed primer와 $2 \mu \mathrm{L}$ 의 1 차 $\mathrm{PCR}$ 산물을 사용하였으며, 2 차 $\mathrm{PCR}$ 의 증폭 조건은 1 차와 동일하게 10 회 반복 수행하였다. 최종 PCR 산물은 AMPure로 정제 후 TapeStation D1000 ScreenTape (Agilent Technologies, Germany)를 사용하여 정량하였다. 
$\mathrm{MiSeq}^{\mathrm{TM}}$ platform (Illumina, USA)을 사용하는 Macrogen사 (Korea)에 염기서열 분석을 의뢰하였으며, Paired-END $(2 \times 300$ bp) 기술을 이용하여 염기서열 분석을 수행하였다.

\subsection{3. $\mathrm{BDOC}$ 분석}

$\mathrm{BAC}$ 컬럼 유입수와 처리수들에 함유된 생물분해 가능한 유기탄소(biodegradable dissolved organic carbon, BDOC) 농 도는 Servais 등의 방법 ${ }^{36)}$ 을 이용하였다. 시료수 중의 유기탄 소가 박테리아 대사의 제한인자로 작용하도록 무기영양염 농 축 cocktail을 주입하였다. ${ }^{37)} 20^{\circ} \mathrm{C}$ 항온배양기에서 28 일간 배 양하여 배양 전·후의 $\mathrm{DOC}$ 농도 차로 $\mathrm{BDOC}$ 농도를 산정하였 다. DOC 농도분석에는 총유기탄소 측정기(Sievers M9, GE, USA)를 사용하였다.

\subsection{4. 유기물질 형광특성 분석 ${ }^{38)}$}

Fluorescence spectrophotometer (Aqualog, Horiba, Japan)를 이용하여 $\mathrm{BAC}$ 컬럼 유입수와 처리수들 내에 잔존하는 용존 유기물질에 대한 형광분석 특성을 평가하였다. Fluorescence spectra는 scan 조건으로 excitation 파장 $240 \sim 400 \mathrm{~nm}(3 \mathrm{~nm}$ 간격), emission 파장 $250 \sim 600 \mathrm{~nm}(2 \mathrm{~nm}$ 간격)로 설정하여 분석하였다. 각 시료수는 잘 세척된 $0.45 \mu \mathrm{m}$ 여지(Millipore, USA)로 여과한 후 형광분석 전에 초순수를 사용하여 시료수 의 $\mathrm{DOC}$ 농도를 $1 \mathrm{mg} / \mathrm{L}$ 로 희석하여 분석에 사용하였다.

\subsection{5. $\mathrm{PO}_{4}-\mathrm{P}$ 분석}

$\mathrm{BAC}$ 컬럼 유입수와 처리수들에 함유된 $\mathrm{PO}_{4}-\mathrm{P}$ 농도분석은 전자동 수질분석기(QuAAtro39, BL Tech, Germany)를 이용하 였다. 시료수 중의 입자상 물질 제거를 위하여 $\mathrm{GF} / \mathrm{C}$ 여지 (Whatman, USA)로 여과한 후 분석하였으며, 정량한계는 $0.001 \mathrm{mg} / \mathrm{L}$ 이다.

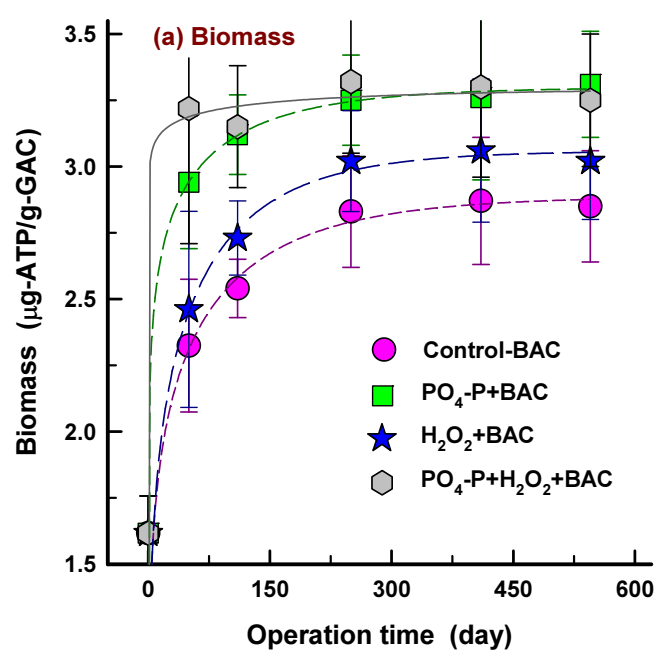

\subsection{6. 통계 분석}

수집된 자료를 SPSS 통계프로그램(ver. 20.0 for window)을 이용하여 요인분석을 실시하였다. 요인추출 방법은 주성분 분 석을 이용하였고, 요인회전 방법은 직각회전 방식인 Varimax 방식을 적용하였다.

\section{3. 결과 및 고찰}

\section{1. 부착 박테리아 생체량 및 활성도}

1 년 6개월간 운전한 재래식 $\mathrm{BAC}$ (control-BAC) 공정과 강 화 $\mathrm{BAC}$ 공정들 $\left(\mathrm{PO}_{4}-\mathrm{P}+\mathrm{BAC}, \mathrm{H}_{2} \mathrm{O}_{2}+\mathrm{BAC}, \mathrm{PO}_{4}-\mathrm{P}+\mathrm{H}_{2} \mathrm{O}_{2}+\mathrm{BAC}\right)$ 의 운전기간 증가에 따른 부착 박테리아 생체량(ATP 농도)과 활성도 변화 결과를 Fig.2에 나타내었다. 부착 박테리아 생체량 (Fig. 2(a))의 경우, $\mathrm{PO}_{4}-\mathrm{P}$ 을 투입한 $\mathrm{BAC}$ 공정들 $\left(\mathrm{PO}_{4}-\mathrm{P}+\mathrm{BAC}\right.$, $\mathrm{PO}_{4}-\mathrm{P}+\mathrm{H}_{2} \mathrm{O}_{2}+\mathrm{BAC}$ )에서는 운전 초기(50일)에 급격한 생체량 의 증가현상을 나타낸 반면, $\mathrm{PO}_{4}-\mathrm{P}$ 를 투입하지 않은 $\mathrm{BAC}$ 공 정들(control-BAC, $\mathrm{H}_{2} \mathrm{O}_{2}+\mathrm{BAC}$ )에서는 운전기간 증가에 따라 지속적인 증가추세를 나타내었다.

Fig.2(b)에 나타낸 운전기간 증가에 따른 부착 박테리아 활 성도 변화 결과에서도 생체량 변화 결과(Fig.2(a))와 유사한 경향을 나타내고는 있으나 활성도의 경우는 대체적으로 대조 군 $\mathrm{BAC}$ 를 비롯하여 강화 $\mathrm{BAC}$ 들 모두에서 운전 초기(50일)의 활성도가 운전기간 550 일 정도까지 소폭 증가한 선에서 유지 되는 경향을 나타내었다.

운전 초기에 급격한 생체량과 활성도의 증가는 정수장에서 2년 정도 사용으로 $\mathrm{BAC}$ 화된 활성탄을 세척하여 사용하였기 때문으로 채집하여 수돗물 세척 후에도 활성탄(BAC)에 박테 리아 군집이 잔존하여 컬럼 운전 초기부터 부착 박테리아 군 집이 급격히 회복한 것으로 판단된다.

재래식 $\mathrm{BAC}$ 공정에 비하여 강화 $\mathrm{BAC}$ 공정들에서의 부착

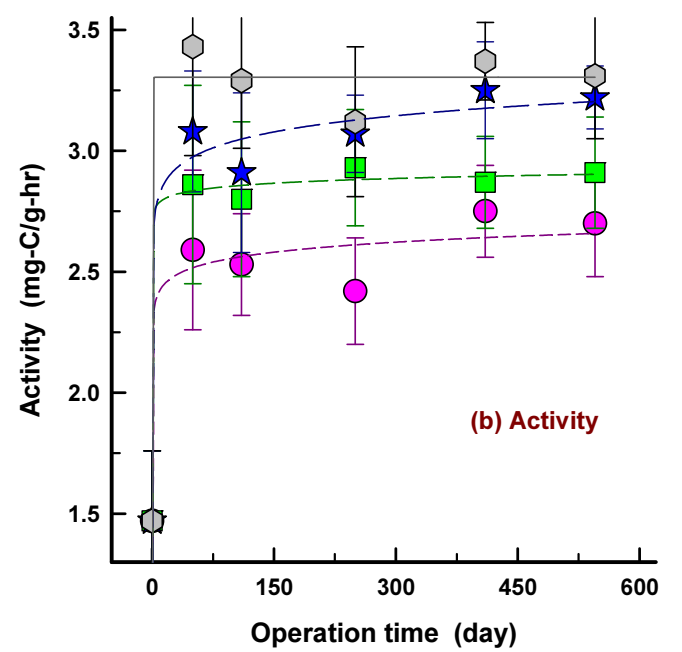

Fig. 2. Changes of attached bacterial biomass (a) and activity $(b)$ of top layer $(\sim-5 \mathrm{~cm})$ of the BAC columns with increasing operation time $(n=3)$. 


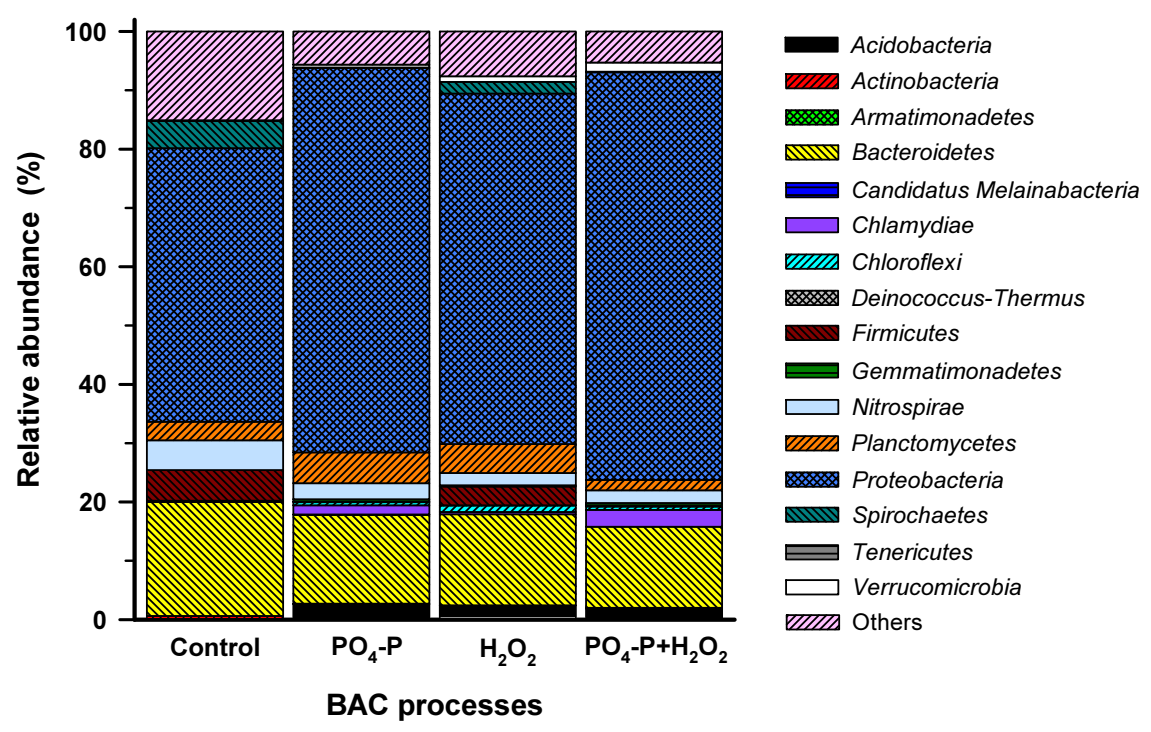

Fig. 3. Related abundance of bacterial communities in the four BAC filters at the phylum.

박테리아 생체량과 활성도 회복능이 훨씬 우수하였으며, $\mathrm{PO}_{4}-\mathrm{P}$ 의 투입은 박테리아의 생체량의 증가속도를 높이고, 투 입된 $\mathrm{H}_{2} \mathrm{O}_{2}$ 는 활성도의 증가속도를 높이는 역할을 수행하는 것으로 평가되었다. ${ }^{14)}$

\section{2. 부착 박테리아 군집 구조}

재래식 $\mathrm{BAC}$ (control)와 강화 $\mathrm{BAC}$ 공정들을 1년 6개월 정도 운전한 이후에 각 컬럼 상층부의 활성탄을 채집하여 부착 박 테리아의 군집구조를 문(phylum) 수준에서 비교한 결과를

Fig. 3 에 나타내었다.

Fig.3에서 볼 수 있듯이 재래식 $\mathrm{BAC}$ 와 강화 $\mathrm{BAC}$ 들 모두에 서 Proteobacteria문이 구성비(46.5 69.3\%)가 가장 높게 나 타났으며, 다음으로 Bacteroidetes 문(19.4\% (대조군), 13.8 $15.5 \%$ (강화 BAC들)), Nitrospirae문(5.0\% (대조군), $2.1 \sim 2.7 \%$ (강화 BAC들)), Planctomycetes 문(3.2\% (대조군), $1.8 \sim 5.2 \%$ (강화 $\mathrm{BAC}$ 들))이었다. Firmicutes 문과 Spirochaetes문의 경우, $\mathrm{PO}_{4}-\mathrm{P}$ 를 투입한 $\mathrm{BAC}$ 들 $\left(\mathrm{PO}_{4}-\mathrm{P}+\mathrm{BAC}, \mathrm{PO}_{4}-\mathrm{P}+\mathrm{H}_{2} \mathrm{O}_{2}+\mathrm{BAC}\right)$ 에 서는 각각 $0.1 \sim 0.2 \%$ 정도의 낮은 구성비를 나타낸 반면, $\mathrm{PO}_{4}-\mathrm{P}$ 를 투입하지 않은 $\mathrm{BAC}$ 들(control-BAC, $\mathrm{H}_{2} \mathrm{O}_{2}+\mathrm{BAC}$ )에 서는 비교적 높은 구성비(2.0 5.2\%)를 나타내었다. 그리고 분 류학적으로 동정되지 않은 비율이 대조군 $\mathrm{BAC}$ 에서는 $15.1 \%$ 인 반면 강화 $\mathrm{BAC}$ 들에서는 $5.3 \sim 7.6 \%$ 로 비교적 낮았다.

정수처리 시스템내 박테리아 군집에 대해 연구한 여러 결과 들에서는 Proteobacteria문이 가장 높은 비율로 우점하는 것으 로 보고하고 있으며 ${ }^{23,39-42)}$, Lautenschlager 등의 연구결과 ${ }^{27)}$ 에 서도 Proteobacteria문이 전체의 39 74\% 정도를 차지했으며, 특히 Rhizobiales강(order)의 우점율이 가장 높은 것으로 보고 하고 있다. 또한, 생물여과 공정에서 박테리아 군집을 연구한 $\mathrm{Oh}$ 등의 연구결과 ${ }^{43)}$ 에서도 Proteobacteria문이 차지하는 비율 이 전체의 $57 \pm 12 \%$ 로 가장 높았고, 다음으로 Bacteroidetes문

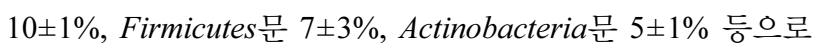
보고하고 있다. Bacteroidetes 문과 Firmicutes 문은 인간 장내의 핵심 미생물군 ${ }^{44)}$ 으로 Acidobacteria문과 함께 토양 생태계에 서 흔히 관찰되는 미생물군이지만 배양에 어려움이 있어 생태 학적 역할에 대해서는 현재까지 명확하게 밝혀지진 않았 다. ${ }^{45,46)}$ Planctomycetes 는 질화(nitrification)를 담당하는 소기 관인 anammoxosome을 포함하고 있으며, 진핵세포 기관과 유 사하게 세포내에 복잡한 구획들을 가지고 있다. ${ }^{47)}$ 한편, 질산 화에 관여 ${ }^{48)}$ 하는 Nitrospirae문은 정수처리 생물여과 공정에 서 상대적으로 높은 비율로 분포하는 것으로 알려져 있다. ${ }^{43,49)}$ Lautenschlager 등의 연구결과 ${ }^{27)}$ 에서도 유입원수 중의 암모니 아 농도가 $4.4 \mathrm{mg} / \mathrm{L}$ (최종 처리수: $1.9 \mathrm{mg} / \mathrm{L}$ )인 정수장의 $\mathrm{BAC}$ 공정에서 Nitrospirae문의 분포비율을 3.3\% 정도로 보고하고 있어 본 연구의 결과 $(2.1 \sim 5.0 \%)$ 와 유사하였다. Kasuga 등 50$)$ 은 암모니아 농도가 $20 \sim 260 \mathrm{mg} \cdot \mathrm{NH}_{4} / \mathrm{L}$ 인 상수원수를 처리하 는 정수장의 $\mathrm{GAC}$ 공정에서 질산화가 관찰된 것으로 보고하고 있다. 본 연구에 사용된 $\mathrm{BAC}$ 공정 유입수 중의 암모니아성 질소 농도범위는 $0.13 \sim 0.45 \mathrm{mg} / \mathrm{L}$ 범위였으며, Lautenschlager 등 $^{27}$ 과 Kasuga 등 $^{50)}$ 의 연구결과와 비교하면 매우 낮은 것으로 평가되지만 Nitrospirae문이 전체의 박테리아 군집에서 차지 하는 비율을 볼 때 각각의 $\mathrm{BAC}$ 공정들에서 질산화가 정수처 리 기작으로 작용하고 있는 것으로 평가되었다. 또한, 지표수 에서 높은 비율로 존재 ${ }^{29)}$ 하는 Actinobacteria문은 재래식 $\mathrm{BAC}$ 와 강화 $\mathrm{BAC}$ 들에서는 $0.04 \sim 0.43 \%$ 의 매우 낮은 구성비를 나타내었으며, 이들은 독립생활을 하며 까다로운 환경 선택성 으로 인해 여재 표면에 대한 부착율이 낮은 것으로 알려져 있다. ${ }^{29)}$ 그러나 대규모 정수장의 최종처리수에 Actinobacteria 가 높은 비율로 존재한다는 보고 ${ }^{39,40)}$ 도 있어 정수장에서 사용 되는 기타 여재(media)나 시설물에 부착하여 서식하는 것으로 알려져 있다. 
재래식 $\mathrm{BAC}$ 공정과 강화 $\mathrm{BAC}$ 공정들의 부착 박테리아 군 집구조를 속(genus) 수준에서 비교한 결과를 Fig.4에 나타내 었다. 많은 속들 중에서 $1 \%$ 이상의 우점율을 나타낸 11 개 문 35 개 속들만을 대상으로 하였다.

Fig.4에서 볼 수 있듯이 재래식 $\mathrm{BAC}$ 와 강화 $\mathrm{BAC}$ 공정들에 서 박테리아 속들의 우점율에는 많은 차이가 있었다. 전체 박테리아 군집에서 가장 높은 구성비를 나타낸 Proteobacteria 문에서는 19 개 속의 박테리아들이 우점하였고, $\alpha-, \beta-, \gamma$ - 및 $\Delta$-Proteobacteria강(Class)에서 각각 9개, 6개, 2개, 2개 속이 우점하였다.

Proteobacteria문 내에서 가장 높은 우점율을 나타낸 $\alpha$ Proteobacteria강의 경우, 강화 $\mathrm{BAC}$ 들에서는 Bradyrhizobium속 (7.9 9.5\%), Sphingomonas 속(5.8 6.4\%), Methylobacterium 속 (4.3 6.4\%), Sphingobium 속(3.0 4.0\%), Belnapia속(1.1 $3.1 \%)$ 과 같은 5 개 속들이 재래식 $\mathrm{BAC}(0.02 \sim 4.0 \%)$ 에 비해 높은 우점율을 보였다. 반면 Hyphomicrobium속, Rhodobacter 속, Sphingopyxis속, Aquidulcibacter속과 같은 4개 속들에서는 재래식 $\mathrm{BAC}$ 에서의 우점율이 각각 $2.0 \sim 5.9 \%$ 로 강화 $\mathrm{BAC}$ 들 에서의 $0.1 \sim 3.3 \%$ 에 비해 높았다. 9 개 우점 속들에서는 강화 $\mathrm{BAC}$ 들 간의 우점율에는 큰 차이는 없었다.

$\alpha$-Proteobacteria강은 빈영양 상태에서 생존능력과 복잡한 유기 화합물의 분해능력이 뛰어난 것으로 알려져 있다. ${ }^{29)}$ 이들은 강과 퇴적물에서 탄수화물 분해효소와 에너지 대사를 위한 유전자를 보유하고 있으며 ${ }^{51)}$, 많은 종이 난분해성 유기 화합물 분해능을 보유하고 있으며, 생물여과 공정 내에 높은 비율로 분포하는 것으로 알려져 있다. ${ }^{52-54)}$ 정수처리 공정 중 다양한 생물여과 공정들에서 박테리아 군집 구조와 분포 에 대해 연구한 $\mathrm{Oh}$ 등의 연구결과 ${ }^{43)}$ 를 보면 $\alpha$-Proteobacteria강 에서 우점율이 높은 속들로는 Afipia속, Bradyrhizobium속, Hyphomicrobium 속, Methylobacterium 속, Nitrobacter속, Rhizobium 속, Rhodopseudomonas속, Sphingomonas속 등이며, 특히, BAC 공정에서는 Bradyrhizobium속(15\%)과 Rhodopseudomonas속 (4\%)이 가장 높은 우점율을 보이는 것으로 보고하고 있다. 활성탄의 세공분포가 $\mathrm{BAC}$ 공정의 성능에 미치는 영향에 대해 연구한 $\mathrm{Lu}$ 등의 연구결과에에서는 전체 박테리아 군집중 에서 $\alpha$-Proteobacteria강의 구성비가 가장 높았고, 그 중에서 Sphingomonas 속(17 24\%)과 Belnapia속(18 22\%)의 우점 율이 가장 높은 것으로 보고하고 있다. Sphingomonas속은 정수 장의 $\mathrm{BAC}$ 여과지에 흔하게 존재하며, 다양한 종류의 유기물을 분해할 수 있는 일반적인 종속 영양 박테리아이다. ${ }^{55,56)}$

$\alpha$-Proteobacteria강 내에서 비교적 높은 우점율을 나타낸 Bradyrhizobium속, Methylobacterium속 및 Hyphomicrobium 속은 Rhizobiales목에 속하며, 이들은 토양 환경 중에 널리 분 포하며, 대사적으로 다양한 특성을 가진다. BAC 공정의 생물 막 군집에 많이 분포하는 것으로 알려져 있으나 활성탄 표면 에 부착하는 메카니즘과 우점종으로서 이들의 역할에 대한
정보는 매우 부족한 실정이다. ${ }^{57)} \mathrm{Oh}$ 등3)은 Rhizobiales목 (Bradyrhizobium 속 등)들에 대한 메타 게놈 분석결과와 많은 연구결과 ${ }^{58,59)}$ 들을 종합하여 $\mathrm{BAC}$ 공정의 유입수 중에 잔존하 는 방향족 NOM의 생물분해에 있어 이들이 매우 중요한 역할 을 수행하며, 변동하는 환경조건에 따라 광범위한 유기기질 을 영양물질로 이용할 수 있는 대사 다양성을 가진 박테리아 군으로 보고하고 있다. 또한, Sphingomonas속, Belnapia속, Sphingobium 속들은 탄수화물 및 아미노산 대사능력이 뛰어나 $\mathrm{BAC}$ 공정 내에서 아미노산 및 탄수화물과 결합된 $\mathrm{NOM}$ 의 생물분해에 관여하는 것으로 알려져 있다. ${ }^{28)} \mathrm{NOM}$ 은 부식질, 아미노산, 탄수화물, 카르복실산 및 단백질 등으로 구성되며 ${ }^{60)}$, 그중 탄수화물과 아미노산이 NOM의 친수성 부분을 구성한다. ${ }^{61)}$

$\beta$-Proteobacteria강의 경우는 강화 BAC들에서 Burkholderia 속(4.8 5.1\%), Polaromonas 속(3.2 4.4\%), Methyloversatilis 속(0.6 2.3\%), Aromatoleum속(0.2 2.9\%) 및 Methylibium속 (1.0 2.1\%)과 같은 5개 속들의 우점율이 재래식 BAC $(0.4$ 3.0\%)에 비해 높게 나타났다. Acidovorax속의 경우는 재래 식과 강화 $\mathrm{BAC}$ 들 모두에서 서로 유사한 우점율(2.4 3.0\%) 을 나타내었다. $\beta$-Proteobacteria강은 비교적 영양이 풍부한 환경에서 잘 성장하는 것으로 알려져 있다. ${ }^{29)} \mathrm{Oh}$ 등의 연구결 과 ${ }^{43)}$ 에서는 Acidovorax속, Burkholderia속, Polaromonas 속 등 이 $\beta$-Proteobacteria강 내에서 높은 우점율을 나타내는 속으로 보고하고 있어 본 연구결과와 유사한 결과를 나타내었다.

$\gamma$-Proteobacteria강과 $\Delta$-Proteobacteria강에서는 각각 Acidibacter속, Succinivibrio속 및 Desulfuromonas속, Chondromyces 속이 우점하였으며, Desulfuromonas속의 경우는 $\mathrm{H}_{2} \mathrm{O}_{2}$ 가 투입 된 $\mathrm{BAC}$ 들에서 높은 우점율(5.0 5.4\%)을 나타내었다.

Bacteroidetes 문에서는 8개 속들이 우점하였으며, Barnesiella 속, Prevotella속, Parabacteroides속 및 Anaerophaga속과 같은 4개의 속들은 거의 재래식 BAC에서만 $2.2 \sim 3.7 \%$ 로 우점한 반면, 강화 $\mathrm{BAC}$ 들에서는 Flavobacterium속, Chryseolinea속, Terrimonas속 및 Ferruginibacter속들이 비교적 높은 우점율을 나타내었다.

Firmicutes 문에서는 Flintibacter속과 Oscillibacter속, Acidobacteria 문에서는 Stenotrophobacter속, Chlamydiae문의 경우는 Neochlamydia속이 우점하였다. Nitrospirae문에서는 Nitrospira 속만이 $2.1 \sim 3.0 \%$ 의 비율로 유사한 우점율을 나타내었으며, Nitrospira속은 BAC 공정뿐만 아니라 완속/급속 여과공정에서 높은 우점율을 보이는 것으로 보고되고 있다. ${ }^{43)}$

Planctomycetes 문의 경우는 Gemmata속과 Pirellula속이 우 점하였으며, Gemmata속은 모든 BAC들에서 $2.0 \sim 3.0 \%$ 의 유 사한 비율로 우점하였다. Gemmata속은 BAC 공정의 박테리 아 군집에서 우점종으로 보고되고 있으며 ${ }^{28)}$, 이들은 호수나 하수처리장에서 서식하며 유기물과 질소를 활용한다. ${ }^{62,63)}$

재래식 $\mathrm{BAC}$ (control) 공정과 강화 $\mathrm{BAC}$ 공정들에서 군집을 구성하고 있는 박테리아 속(genus)들의 구성비를 이용하여 주 


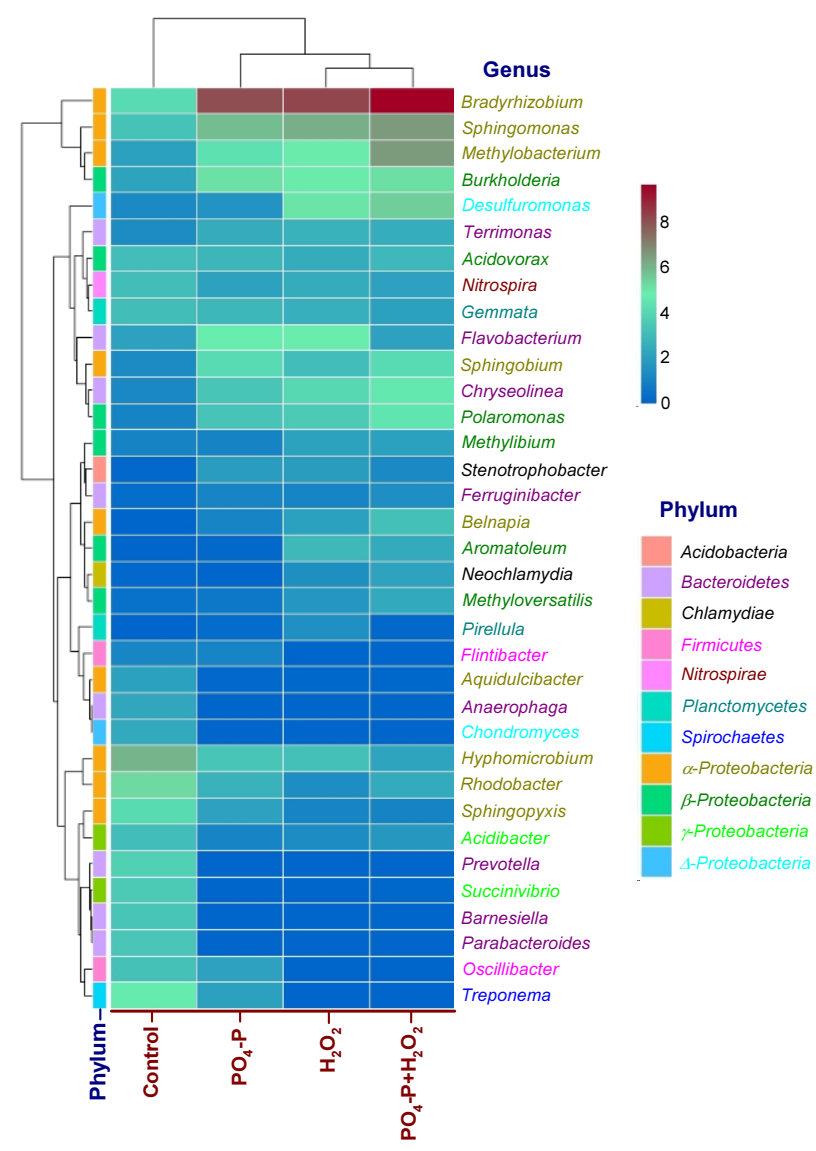

Fig. 4. Heatmap of the relative abundances of the top 35 bacterial at the genus level in BAC columns samples.

성분(principle component, PC) 분석을 수행한 결과를 Fig.5에 나타내었다. Fig.5에서 볼 수 있듯이 각 BAC 공정별 분포패턴 의 경우 명확하게 2 개의 그룹으로 나뉘어지는 것을 볼 수 있 다. Fig.4에서 볼 수 있듯이 재래식 BAC의 경우 몇몇 속들을 제외하고는 강화 $\mathrm{BAC}$ 들과는 구성비에 많은 차이를 나타내어 재래식 $\mathrm{BAC}$ 가 하나의 그룹(그룹 1)을 형성하였으며, 강화 $\mathrm{BAC}$ 들이 또 다른 그룹(그룹 2)을 형성하였다. 이들에서는 Bradyrhizobium속, Methylobacterium 속 및 Hyphomicrobium 속, Sphingomonas속 및 Burkholderia속의 구성비가 재래식 $\mathrm{BAC}$ 에 비하여 높은 것으로 나타났다.

낙동강 하류의 대형 정수장들은 중·상류에 위치한 많은 공단과 대도시의 하수처리장에서 방류된 다양한 난분해성 오염물질들이 함유된 원수를 이용한다. ${ }^{38,64)}$ 이들 정수장에서 운영 중인 $\mathrm{O}_{3} / \mathrm{BAC}$ 공정의 부착 생물막에 난분해성 $\mathrm{NOM}$ 을 비롯한 다양한 유기기질들에 대해 광범위한 대사능을 가진 $\alpha$-Proteobacteria강 구성원들의 우점율이 높을수록 $\mathrm{BAC}$ 처리 수의 수질 측면에서 매우 유리하다.

Fig. 6에는 기존의 재래식 BAC 공정(control-BAC)과 강화 $\mathrm{BAC}$ 공정들 중 $\mathrm{PO}_{4}-\mathrm{P}$ 와 $\mathrm{H}_{2} \mathrm{O}_{2}$ 를 함께 투입한 $\mathrm{PO}_{4}-\mathrm{P}+\mathrm{H}_{2} \mathrm{O}_{2}+$ $\mathrm{BAC}$ 에서의 $\mathrm{BDOC}$ 제거능을 두 단계(안정화 단계 이전과 이 후)로 나누어 평가한 결과를 나타내었다. $\mathrm{BDOC}$ 제거능은 각

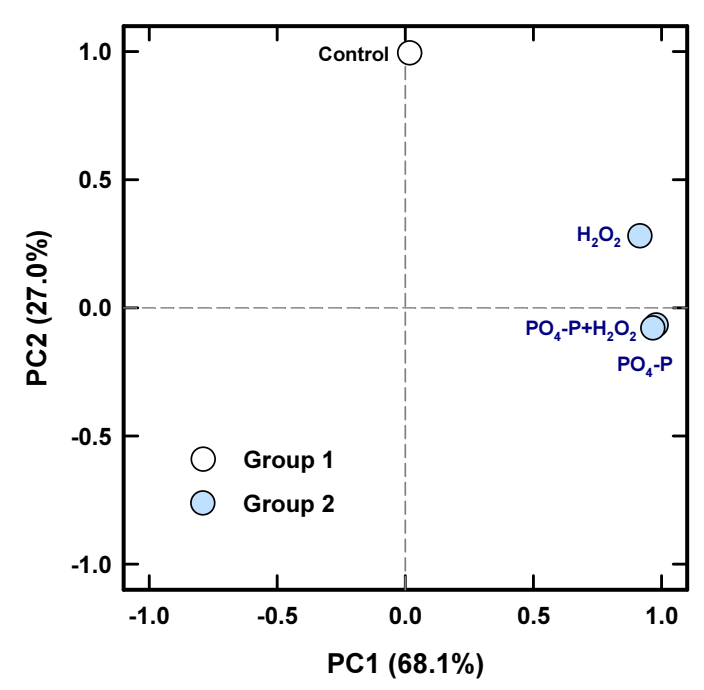

Fig. 5. Similarity of bacterial community for the four BAC filters at the genus level.

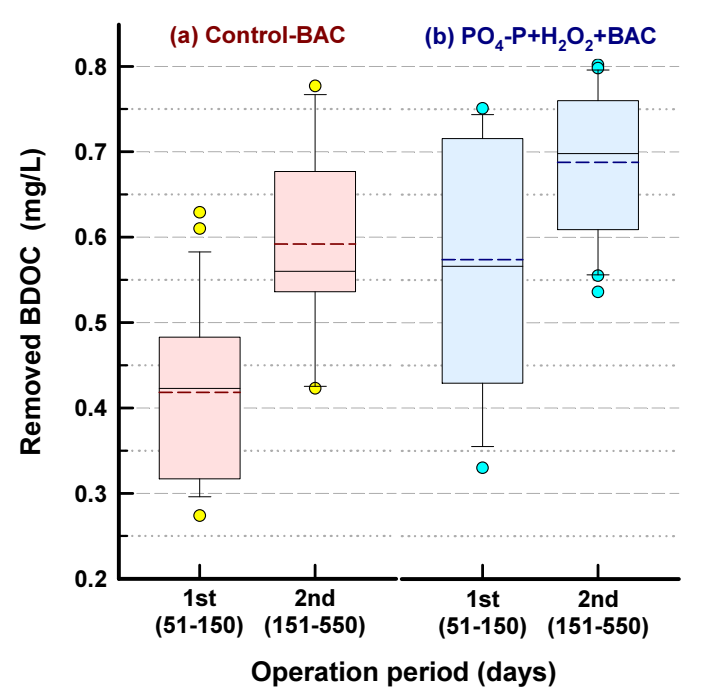

Fig.6. The removal of $B D O C$ in conventional and enhanced BAC process.

$\mathrm{BAC}$ 컬럼들에서의 순응 기간 50 일을 제외하고 평가하였다. 안정화 단계 이전(운전시작 후 $51 \sim 150$ 일)에 제거된 $\mathrm{BDOC}$ 의 평균농도는 재래식 $\mathrm{BAC}$ 와 $\mathrm{PO}_{4}-\mathrm{P}+\mathrm{H}_{2} \mathrm{O}_{2}+\mathrm{BAC}$ 에서 각각 0.42 $\mathrm{mg} / \mathrm{L}$ (평균 제거율 $66 \%$ )와 $0.57 \mathrm{mg} / \mathrm{L}$ (평균 제거율 $89 \%$ )로 나타나 $0.15 \mathrm{mg} / \mathrm{L}$ 의 $\mathrm{BDOC}$ 농도 차이를 보였으며, 평균 제거 율은 $23 \%$ 정도 차이를 나타내었다. 또한, 안정화 단계 이후(운 전시작 후 $151 \sim 550$ 일)에는 제거된 $\mathrm{BDOC}$ 의 평균농도가 각 각 $0.59 \mathrm{mg} / \mathrm{L}$ (평균 제거율 $83 \%$ )와 $0.69 \mathrm{mg} / \mathrm{L}$ (평균 제거율 $97 \%)$ 로 나타나 $0.10 \mathrm{mg} / \mathrm{L}$ 의 $\mathrm{BDOC}$ 농도 차이를 나타내었으 며, 평균 제거율의 경우는 $14 \%$ 정도 차이를 보였다. Fig.7에 나타낸 형광 스펙트럼들에서도 볼 수 있듯이 $\mathrm{BAC}$ 유입수에 잔존하던 휴믹 유사 성분과 단백질 유사 성분의 peak들이 재 래식 $\mathrm{BAC}$ 공정에서 보다 인과 과산화수소를 투입한 강화 $\mathrm{BAC}$ 공정에서 훨씬 많이 감소되는 것을 볼 수 있다. 이러한 

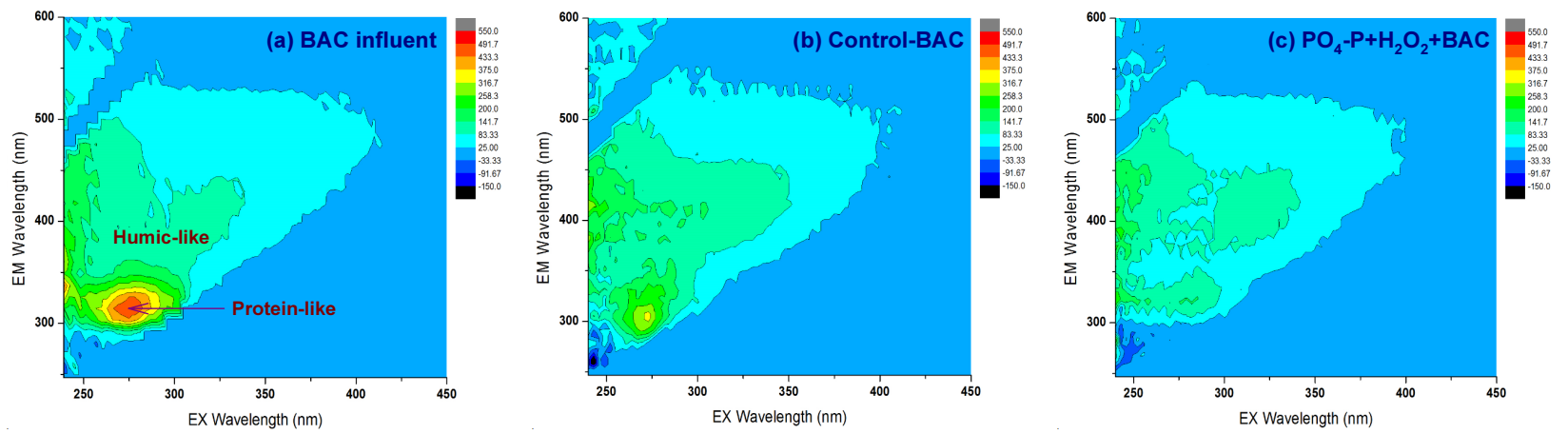

Fig. 7. Fluorescence excitation emission matrix analysis for the conventional and enhanced BAC filter treated waters.

각각의 peak들은 $\mathrm{BDOC}$ 를 구성하는 주요 성분들이다.

정수장의 최종 처리수 중의 $\mathrm{BDOC}$ 농도가 $0.15 \mathrm{mg} / \mathrm{L}$ 이하이 면 잔류염소가 존재하지 않아도 배·급수관망에서 생물학적으 로 안전한 것으로 보고되었다. ${ }^{65}$ 이러한 기준을 적용해 볼 때, 안정화 단계 전·후로 재래식 $\mathrm{BAC}$ 공정 처리수 중에 잔존하는 평균 $\mathrm{BDOC}$ 농도는 각각 $0.22 \mathrm{mg} / \mathrm{L}$ 와 $0.14 \mathrm{mg} / \mathrm{L}$ 로 나타나 관망에서 잔류염소 농도가 감소하면 생물학적 안전성이 위협 받을 가능성이 존재하였다. 반면, $\mathrm{PO}_{4}-\mathrm{P}+\mathrm{H}_{2} \mathrm{O}_{2}+\mathrm{BAC}$ 처리수 의 경우는 안정화 단계 전·후로 처리수 중에 잔존하는 평균 $\mathrm{BDOC}$ 농도가 각각 $0.12 \mathrm{mg} / \mathrm{L}$ 와 $0.02 \mathrm{mg} / \mathrm{L}$ 로 나타나 관망에 서의 생물학적 안전성에는 문제가 없는 것으로 평가되었다.

유기물질 제거능의 이러한 차이는 인산염과 과산화수소 투입으로 부착 박테리아의 생체량과 활성도(Fig. 2)뿐 만 아니라 광범위한 유기기질들에 대해 우수한 대사능을 가진 Bradyrhizobium속, Methylobacterium속, Sphingomonas 속, Belnapia속, Sphingobium속들의 우점율 또한 재래식 $\mathrm{BAC}$ 공정에 비해 강화 $\mathrm{BAC}$ 공정들에서 월등히 높았기 때문으로 평가되었다.

\section{4. 결론}

본 연구에서는 1년 6개월 동안 낙동강 하류원수를 대상으로 정수처리하는 파일럿 플랜트를 이용하여 인산염 $\left(\mathrm{PO}_{4}-\mathrm{P}\right)$ 과 과 산화수소 $\left(\mathrm{H}_{2} \mathrm{O}_{2}\right)$ 를 투입하는 강화 $\mathrm{BAC}$ 공정의 향상된 유기물 질 제거능과 부착 박테리아 군집과의 연관성을 평가하였다.

강화 $\mathrm{BAC}$ 공정에서 장기간 투입된 인산염 $\left(\mathrm{PO}_{4}-\mathrm{P}\right)$ 은 부착 박테리아의 생체량의 증가에 기여하였고, 과산화수소 $\left(\mathrm{H}_{2} \mathrm{O}_{2}\right)$ 는 부착 박테리아의 활성도 증진에 기여하였다. 재래식 $\mathrm{BAC}$ 공정과 강화 $\mathrm{BAC}$ 공정들의 부착 박테리아 군집에서 는 Proteobacteria문의 우점율이 가장 높았으며, $\alpha$ - 및 $\beta$ -Proteobacteria강의 우점율이 높게 나타났다. 박테리아 군집 내 다양한 속(genus)들의 구성비율을 바탕으로 한 박테리아 군집 유사도의 경우, 강화 $\mathrm{BAC}$ 들은 서로 유사하게 나타났으 며, 재래식 $\mathrm{BAC}$ 공정과는 명확하게 구분되었다. 특히, 광범위 한 유기기질들에 대해 우수한 대사능을 가진 Bradyrhizobium
속, Sphingomonas속, Methylobacterium속, Sphingobium속, Belnapia속, Burkholderia속, Polaromonas속, Desulfuromonas 속들이 강화 $\mathrm{BAC}$ 공정들에서 높은 비율로 우점하여 재래식 $\mathrm{BAC}$ 공정과는 많은 차이를 나타내었다. $\mathrm{BDOC}$ 제거능으로 평가된 처리수의 수질의 경우도 재래식 $\mathrm{BAC}$ 공정에서는 처리 수 중의 $\mathrm{BDOC}$ 농도가 $0.15 \mathrm{mg} / \mathrm{L}$ 부근으로 나타나 관망에서 잔류염소 농도가 감소하면 생물학적 안전성이 위협받을 가능 성이 존재한 반면, 인산염 $\left(\mathrm{PO}_{4}-\mathrm{P}\right)$ 과 과산화수소 $\left(\mathrm{H}_{2} \mathrm{O}_{2}\right)$ 를 투입 한 강화 $\mathrm{BAC}$ 공정 처리수에서는 평균 $\mathrm{BDOC}$ 농도가 0.15 $\mathrm{mg} / \mathrm{L}$ 미만으로 나타나 관망에서 생물학적 안전성을 확보할 수 있었다.

\section{References}

1. H. J. Son, S. J. Yoo, J. S. Roh, P. J. Yoo, Biological activated carbon (BAC) process in water treatment, J. Korean Soc. Environ. Eng., 31(4), 308-323(2009).

2. C. Liu, C. I. Olivares, A. J. Pinto, C. V. Lauderdale, J. Brown, M. Selbes, T. Karanfil, The control of disinfection byproducts and their precursors in biologically active filtration processes, Water Res., 124, 630-653(2017).

3. D. M. Son, H. J. Son, H. J. Lee. L. S. Kang, Removal of geosmin and 2-MIB using biological activated carbon process, J. Korean Soc. Water Wastewater, 23(2), 189-198 (2009).

4. J. Fu, W. N. Lee, C. Coleman, K. Nowack, J. Carter, C. H. Huang, Removal of pharmaceuticals and personal care products by two-stage biofiltration for drinking water treatment, Sci. Total Environ., 664, 240-248(2019).

5. W. A. M. Hijnen, R. Schurer, J. A. Bahlman, H. A. M. Ketelaars, R. Italiaander, A. van der Wal, P. W. J. J. van der Wielen, Slowly biodegradable organic compounds impact the biostability of non-chlorinated drinking water produced from surface water, Water Res., 129, 240-251(2018).

6. N. Moona, U. J. Wünsch, M. Bondelind, O. Bergstedt, T. Sapmaz, T. J. R. Pettersson, K. R. Murphy, Temperature-dependent mechanisms of DOM removal by biological activated carbon filters, Environ. Sci.: Water Res. Technol., 5(12), 2232-2241(2019). 
7. H. J. Son, H. K. Park, S. A. Lee, E. Y. Jung, C. W. Jung, The characteristics of microbial community for biological activated carbon in water treatment plant, J. Korean Soc. Environ. Eng., 27(12), 1311-1320(2005).

8. H. J. Son, S. W. Kang, H. S. Yoom, D. C. Ryu, M. G. Cho, Evaluation of biodegradation kinetic in biological activated carbon (BAC) process for drinking water treatment: effects of EBCT and water temperature, J. Korean Soc. Environ. Eng., 37(7), 404-411(2015).

9. S. G. Kim, H. G. Park, H. J. Son, H. S. Yoom, D. C. Ryu, Evaluation of influence factors for determination of proper backwashing time of biological activated carbon (BAC) process in drinking water treatment process, J. Environ. Sci. Int., 24(12), 1551-1558(2015).

10. M. Selbes, J. Amburgey, C. Peeler, A. Alansari, T. Karanfil, Evaluation of seasonal performance of conventional and phosphate-amended biofilters, J. Am. Water Works Assoc., 108(10), E523-E532(2016).

11. X. Dong, L. Bäcker, M. Rahmatullah, D. Schunk, G. Lens, R. U. Meckenstock, Quantification of microbial degradation activities in biological activated carbon filters by reverse stable isotope labelling, AMB Expr., 9, 109(2019).

12. C. Lauderdale, P. Chadik, M. J. Kirisits, J. Brown, Engineered biofiltration: enhanced biofilter performance through nutrient and peroxide addition, J. Am. Water Works Assoc., 104(5), E298-E309(2012).

13. J. H. Noh, S. H. Yoo, H. Son, K. E. Fish, I. Douterelo, S. K. Maeng, Effects of phosphate and hydrogen peroxide on the performance of a biological activated carbon filter for enhanced biofiltration, J. Hazard. Mater., 388, 121778(2020).

14. H. Son, E. Y. Jung, H. S. Yoom, S. G. Kim, S. K. Maeng, Application of enhanced BAC process for improving drinking water treatment efficiency, J. Korean Soc. Environ. Eng., 42(6), 298-307(2020).

15. W. Nishijima, E. Shoto, M. Okada, Improvement of biodegradation of organic substance by addition of phosphorus in biological activated carbon, Water Sci. Technol., 36(12), 251-257(1997).

16. S. E. Keithley, M. J. Kirisits, Enzyme-identified phosphorus limitation linked to more rapid headloss accumulation in drinking water biofilters, Environ. Sci. Technol., 53(4), 2027-2035(2019).

17. M. W. LeChevallier, W. Schulz, R. G. Lee, Bacterial nutrients in drinking water, Appl. Environ. Microbiol., 57(3), 857-862 (1991).

18. D. L. Pardieck, E. J. Bouwer, A. T. Stone, Hydrogen peroxide use to increase oxidant capacity for in situ bioremediation of contaminated soils and aquifers: a review, J. Contam. Hydrol., 9(3), 221-242(1992).

19. B. E. Christensen, H. N. Trønnes, K. Vollan, O. Smidsrød, R. Bakke, Biofilm removal by low concentration of hydrogen peroxide, Biofouling, 2(2), 165-175(1990).

20. E. Neyens, J. Baeyens, M. Weemaes, B. D. Heyder, Advanced biosolids treatment using $\mathrm{H}_{2} \mathrm{O}_{2}$ oxidation, Environ. Eng. Sci., 19(1), 27-35(2002).
21. B. E. Rittmann, Microbial ecology to manage processes in environmental biotechnology, Trends Biotechnol., 24, 261-266 (2006).

22. S. Velten, D. R. U. Knappe, J. Traber, H. P. Kaiser, U. von Gunten, M. Boller, S. Meylan, Characterization of natural organic matter adsorption in granular activated carbon adsorbers, Water Res., 45(13), 3951-3959(2011).

23. X. Liao, C. Chen, Z. Wang, R. Wan, C. H. Chang, X. Zhang, S. Xie, Pyrosequencing analysis of bacterial communities in drinking water biofilters receiving influents of different types, Process Biochem., 48(4), 703-707(2013).

24. O. E. Kaarela, H. A. Harkki, M. R. T. Palmroth, T. A. Tuhkanen, Bacterial diversity and active biomass in full-scale granular activated carbon filters operated at low water temperatures, Environ. Technol., 36(6), 681-692(2015).

25. V. A. Nemani, M. J. Mckie, L. Taylor-Edmonds, R. C. Andrews, Impact of biofilter operation on microbial community structure and performance, J. Water Process Eng., 24, 35-41(2018).

26. M. Vignola, D. Werner, M. J. Wade, P. Meynet, R. J. Davenport, Medium shapes the microbial community of water filters with implications for effluent quality, Water Res., 129, 499-508(2018).

27. K. Lautenschlager, C. Hwang, F. Ling, W. T. Liu, N. Boon, O. Köster, T. Egli, F. Hammes, Abundance and composition of indigenous bacterial communities in a multi-step biofiltration-based drinking water treatment plant, Water Res., 62, 40-52(2014).

28. Z. Lu, W. Sun, C. Li, W. Cao, Z. Jing, S. Li, X. Ao, C. Chen, S. Liu, Effect of granular activated carbon pore-size distribution on biological activated carbon filter performance, Water Res., 177, 115768(2020).

29. R. J. Newton, S. E. Jones, A. Eiler, K. D. McMahon, S. Bertilsson, A guide to the natural history of freshwater lake bacteria, Microbiol. Mol. Biol. Rev., 75(1), 14-49(2011).

30. Y. Chao, Y. Mao, Z. Wang, T. Zhang, Diversity and functions of bacterial community in drinking water biofilms revealed by high-throughput sequencing, Sci. Rep., 5, 10044(2015).

31. E. M. Fykse, T. Aarskaug, E. H. Madslien, M. Dybwad, Microbial community structure in a full-scale anaerobic treatment plant during start-up and first year of operation revealed by high-throughput 16S rRNA gene amplicon sequencing, Bioresour. Technol., 222, 380-387(2016).

32. I. Douterelo, J. B. Boxall, P. Deines, R. Sekar, K. E. Fish, C. A. Biggs, Methodological approaches for studying the microbial ecology of drinking water distribution systems, Water Res., 65, 134-156(2014).

33. L. Sinclair, O. A. Osman, S. Bertilsson, A. Eiler, Microbial community composition and diversity via 16S rRNA gene amplicons: evaluating the Illumina platform, PLoS One, 10(2), e011695(2015).

34. S. Velten, F. Hammes, M. Boller, T. Egli, Rapid and direct estimation of active biomass on granular activated carbon through adenosine tri-phosphate (ATP) determination, Water Res., 41(9), 1973-1983(2007). 
35. H. J. Son, J. K. Lee, S. G. Kim, H. K. Park, E. Y. Jung, Removal characteristics of geosmin and MIB in BAC process : biodegradation and adsorption, J. Korean Soc. Environ. Eng., 39(6), 318-324(2017).

36. P. Servais, G. Billen, M. C. Hascoët, Determination of the biodegradable fraction of dissolved organic matter in waters, Water Res., 21(4), 445-450(1987).

37. S. Goel, R. M. Hozalski, E. J. Bouwer, Biodegradation of NOM: effect of NOM source and ozone dose, J. Am. Water Works Assoc., 87(1), 90-105(1995).

38. Y. S. Kim, H. J. Son, C. D. Seo, H. Y. Kim, W. T. Lee, I. S. Hwang, Evaluation of NOM characteristics and disinfection by-products (DBPs) formation potential in Nakdong River basin, J. Korean Soc. Environ. Eng., 40(12), 495-504(2018).

39. D. N. Zeng, Z. Y. Fan, L. Chi, X. Wang, W. D. Qu, Z. X. Quan, Analysis of the bacterial communities associated with different drinking water treatment processes, World J. Microbiol. Biotechnol., 29, 1573-1584(2013).

40. W. Lin, Z. Yu, H. Zhang, I. P. Thompson, Diversity and dynamics of microbial communities at each step of treatment plant for potable water generation, Water Res., 52, 218-230 (2014).

41. X. Liao, C. Chen, Z. Wang, R. Wan, C. H. Chang, X. Zhang, S. Xie, Changes of biomass and bacterial communities in biological activated carbon filters for drinking water treatment, Process Biochem., 48(2), 312-316(2013).

42. I. Vaz-Moreira, C. Egas, O. C. Nunes, C. M. Manaia, Bacterial diversity from the source to the tap: a comparative study based on 16S rRNA gene-DGGE and culture-dependent methods, FEMS Microbiol. Ecol., 83(2), 361-374(2013).

43. S. Oh, F. Hammes, W. T. Liu, Metagenomic characterization of biofilter microbial communities in a full-scale drinking water treatment plant, Water Res., 128, 278-285(2018).

44. J. G. Caporaso, C. L. Lauber, E. K. Costello, D. Berg-Lyons, A. Gonzalez, J. Stombaugh, D. Knights, P. Gajer, J. Ravel, N. Fierer, J. I. Gordon, R. Knight, Moving pictures of the human microbiome, Genome Biol., 12(5), R50(2011).

45. S. A. Eichorst, J. A. Breznak, T. M. Schmidt, Isolation and characterization of soil bacteria that define Terriglobus gen. nov., in the phylum Acidobacteria, Appl. Environ. Microbiol., 73(8), 2708-2717(2007).

46. A. M. Kielak, C. C. Barreto, G. A. Kowalchuk, J. A. van Veen, E. E. Kuramae, The ecology of Acidobacteria: moving beyond genes and genomes, Front. Microbiol., 7, 744(2016).

47. J. A. Fuerst, E. Sagulenko, Beyond the bacterium: planctomycetes challenge our concepts of microbial structure and function, Nat. Rev. Microbiol., 9, 403-413(2011).

48. S. Lucker, M. Wagner, F. Maixner, E. Pelletier, H. Koch, B. Vacherie, T. Rattei, J. S. S. Damste, E. Spieck, D. Le Paslier, H. Daims, A Nitrospira metagenome illuminates the physiology and evolution of globally important nitrite-oxidizing bacteria, Proc. Natl. Acad. Sci. U.S.A., 107(30), 13479-13484(2010).

49. S. Feng, C. Chen, Q. F. Wang, X. J. Zhang, Z. Y. Yang, S. G. Xie, Characterization of microbial communities in a granular activated carbon-sand dual media filter for drinking water treatment, Int. J. Environ. Sci. Technol., 10, 917-922 (2013).

50. I. Kasuga, H. Nakagaki, F. Kurisu, H. Furumai, Predominance of ammonia-oxidizing archaea on granular activated carbon used in a full-scale advanced drinking water treatment plant, Water Res., 44(17), 5039-5049(2010).

51. B. Reddy, J. Pandey, S. K. Dubey, Assessment of environmental gene tags linked with carbohydrate metabolism and chemolithotrophy associated microbial community in River Ganga, Gene, 704, 31-41(2019).

52. F. Emtiazi, T. Schwartz, S. M. Marten, P. Krolla-Sidenstein, U. Obst, Investigation of natural biofilms formed during the production of drinking water from surface water embankment filtration, Water Res., 38(5), 1197-1206(2004).

53. Y. Zhu, H. Wang, X. Li, C. Hu, M. Yang, J. Qu, Characterization of biofilm and corrosion of cast iron pipes in drinking water distribution system with $\mathrm{UV} / \mathrm{Cl}_{2}$ disinfection, Water Res., 60, 174-181(2014).

54. Y. Peng, J. Li, J. Lu, L. Xiao, L. Yang, Characteristics of microbial community involved in early biofilms formation under the influence of wastewater treatment plant effluent, J. Environ. Sci., 66, 113-124(2018).

55. S. Jeong, K. Cho, D. Jeong, S. Lee, T. Leiknes, S. Vigneswaran, H. Bae, Effect of engineered environment on microbial community structure in biofilter and biofilm on reverse osmosis membrane, Water Res., 124, 227-237(2017).

56. H. Liu, L. Zhu, X. Tian, Y. Yin, Seasonal variation of bacterial community in biological aerated filter for ammonia removal in drinking water treatment, Water Res., 123, 668-677(2017).

57. R. M. Niemi, I. Heiskanen, R. Heine, J. Rapala, Previously uncultured $\beta$-Proteobacteria dominate in biologically active granular activated carbon (BAC) filters, Water Res., 43(20), 5075-5086(2009).

58. S. Latha, A. Mahadevan, Role of rhizobia in the degradation of aromatic substances, World J. Microbiol. Biotechnol., 13, 601-607(1997).

59. Y. Teng, X. Wang, L. Li, Z. Li, Y. Luo, Rhizobia and their bio-partners as novel drivers for functional remediation in contaminated soils, Front. Plant Sci., 6, 32(2015).

60. J. P. Croué, G. V. Korshin, M. M. Benjamin, Characterization of Natural Organic Matter in Drinking Water, American Water Works Association Research Foundation, Denver, Colorado(2010).

61. T. Bond, E. H. Goslan, S. A. Parsons, B. Jefferson, A critical review of trihalomethane and haloacetic acid formation from natural organic matter surrogates, Environ. Technol. Rev., 1(1), 93-113(2012).

62. H. Bae, K. S. Park, Y. C. Chung, J. Y. Jung, Distribution of anammox bacteria in domestic WWTPs and their enrichments evaluated by real-time quantitative PCR, Process Biochem., 45(3), 323-334(2010).

63. W. Zhang, Y. Zhou, E. Jeppesen, L. Wang, H. Tan, J. Zhang, Linking heterotrophic bacterioplankton community composition 
to the optical dynamics of dissolved organic matter in a large eutrophic Chinese lake, Sci. Total Environ., 679, 136-147(2019).

64. H. S. Yoom, H. J. Son, K. A. Kim, H. Y. Kim, D. C. Ryu, Occurrence of benzotriazoles, benzothiazoles and benzenesulfonamides in the wastewater treatment plant effluents in Nakdong River basin, J. Korean Soc. Environ. Eng., 40(3), 147-154(2018).

65. P. Laurent, P. Servais, M. Prévost, D. Gatel, B. Clément, Testing the Sancho model on distribution systems, J. Am. Water Works Assoc., 89(7), 92-103(1997).

\section{Declaration of Competing Interest}

The authors declare that they have no known competing financial interests or personal relationships that could have appeared to influence the work reported in this paper.

\section{Authors and Contribution Statement}

\section{Eun-Young Jung}

Water Quality Institute, Busan Water Authority, Researcher, ORCID(D) 0000-0003-4053-7585: Methodology, Validation.

\section{Byungryul An}

Department of Civil Engineering, Sangmyung University, Professor, ORCID (1) 0000-0003-4341-6770: Conceptualization, Methodology, Writing - review and editing.

\section{Heejong Son}

Water Quality Institute, Busan Water Authority, Researcher, ORCID (1) 0000-0002-7950-8223: Conceptualization, Methodology, Validation, Writing - original draft. 